\title{
Different mode of circulating immune complexes and anti-ssDNA antibodies in sera of lepromatous leprosy and systemic lupus erythematosus
}

\author{
FUKUMI FURUKAWA, ${ }^{*} \ddagger$ HARUYOSHI \\ YOSHIDA, ${ }^{*}$ KENICHI SEKITA, ${ }^{*}$ MOTOAKI OZAKI, $\dagger$ \\ SADAO IMAMURA $\dagger \&$ YOSHIHIRO \\ HAMASHIMA* \\ From the Department of Pathology* and Dermatology†, Faculty of \\ Medicine, Kyoto University, Sakyo, Kyoto 606, Japan
}

Accepted for publication 2 February 1984

\begin{abstract}
Summary Circulating immune complexes (CIC) and anti-ssDNA antibody were detected in sera of the patients with lepromatous leprosy (LL) and systemic lupus erythematosus (SLE). There was a markedly quantitative difference in the level of CIC and anti-ssDNA antibody between LL and SLE. Quantitative correlation study showed a lack of association between these 2 serological tests in LL but a significant association in SLE. In addition, ssDNA was not demonstrable in CIC of LL.

These findings suggest that the mode of the appearance of these serological abnormalities in LL was completely different from that in autoimmune disease like SLE and might be the result of polyclonal B cell activation, whose causative factors seemed to be different from those of SLE.
\end{abstract}

\section{Introduction}

It is well known that circulating immune complexes (CIC) and some auto-antibodies are demonstrated in sera of patients with lepromatous leprosy (LL).$^{1,2}$ These serological abnormalities are also frequently found in systemic lupus erythematosus (SLE) and have diagnostic value. We have reported the presence of CIC and anti single-stranded (ss)DNA antibody in sera of patients with LL. ${ }^{3,4}$ Of special interest is whether or not LL belongs to the spectrum of autoimmune disease and another interesting point is what kinds of antigen are involved in CIC of LL and SLE.

‡ Correspondence: Fukumi Furukawa, Department of Pathology, Faculty of Medicine, Kyoto University, Sakyo, Kyoto 606, Japan. 
In this report we designed the comparative analysis of mode of the appearance of CIC and anti-ssDNA antibody in patients with LL and discussed the difference of serological abnormalities in LL compared with SLE.

\section{Material and method}

Serum samples obtained from 53 patients with LL, which was diagnosed according to the criteria of Ridley-Jopling classification, ${ }^{5}$ were studied. Their age ranged from 20 to 76 years. Clinical stage was divided into 2 groups, that is, active stage and inactive stage according to the criteria of Japanese leprosy committee. ${ }^{6}$ The patient number of each group was 21 and 32 respectively. All patients were under the treatment of anti-leprosy agents but without corticosteroids. Patients with systemic infectious disease, cancer, liver disease and autoimmune disease were excluded from the protocol.

Serum sample was collected from 61 patients with SLE who visited the Departments of Internal Medicine and Dermatology, Kyoto University Hospital. These patients satisfied the diagnostic criteria of the American Rheumatism Association for SLE. ${ }^{7}$ Their age ranged from 8 to 45 years. Activity of SLE was judged by the presence of at least 2 of the following items: (1) facial erythema; (2) arthralgia; (3) Raynaud's phenomenon; (4) unexplained fever; (5) central nerve abnormalities; (6) serositis; (7) onset of edema; (8) hypertension; (9) LE cells; (10) leukopenia; and (11) proteinuria. Twenty-five serum samples as control were obtained from healthy individuals whose age ranged from 25 to 79 years. All sera were stored at $-80^{\circ} \mathrm{C}$ until use.

CIC were detected by $\mathrm{Clq}$ solid phase assay which was performed as a modification of the method of Hay, Nineham \& Roitt. ${ }^{8}$ Briefly, removal microtiter wells (Cooke, USA) were coated with $100 \mu \mathrm{l}$ of Clq solution at a concentration of $10 \mu \mathrm{g} / \mathrm{ml}$ at $4{ }^{\circ} \mathrm{C}$ for $20 \mathrm{~h}$, and further incubated with $1 \%$ BSA-PBS. Twenty $\mu$ l of test sample was incubated with $80 \mu 10 \cdot 2 \mathrm{M}$-EDTA-2Na $\left(\mathrm{pH} 7.4\right.$ ) at $37^{\circ} \mathrm{C}$ for $30 \mathrm{~min}$. To these mixtures, $500 \mu \mathrm{l}$ of $0.05 \%$-Tween 20 -PBS was added; $100 \mu \mathrm{l}$ of this mixture was transferred to the Clq coated well in duplicate, and incubated at $37^{\circ} \mathrm{C}$ for $1 \mathrm{~h}$ and $4^{\circ} \mathrm{C}$ for $30 \mathrm{~min}$. After washing 3 times, each well was incubated with $100 \mu \mathrm{l}$ of ${ }^{125} \mathrm{I}$-protein $\mathrm{A}$ at $37^{\circ} \mathrm{C}$ for $2 \mathrm{~h}$. After washing 3 times, radioactivity was counted. According to our previous report, ${ }^{3}$ levels and cut-off point were determined and statistical analysis was made.

When the effects of ssDNA on CIC were determined, $100 \mu \mathrm{l}$ of ssDNA solution was added before incubation with ${ }^{125}$ I-protein A. The ssDNA was prepared by heating calf thymus DNA (Worthington Diagnostics, USA) at $100^{\circ} \mathrm{C}$ for $10 \mathrm{~min}$, then immediately cooling in an ice bath. The ssDNA was diluted with $1 \mathrm{mM}$ EDTA-PBS ( $\mathrm{pH} 7 \cdot 4)$ at varying concentrations (10 
$\mu \mathrm{g} / \mathrm{ml}-1 \mathrm{mg} / \mathrm{ml})$. The results of inhibition were expressed as per cent inhibition of $\mathrm{Clq}$ binding activity, calculated as follows:

$$
\% \text { inhibition }=\left(1-\frac{\mathrm{cpm} \text { in the presence of ssDNA }- \text { background }}{\mathrm{cpm} \text { in the absence of ssDNA }- \text { background }}\right) \times 100
$$

The background represents the cpm of the wells without C1q solution.

Modified Farr assay ${ }^{9}$ was employed for the detection of anti-ssDNA antibody in sera, which was described recently. ${ }^{4}$ Briefly, the reaction mixture $(200 \mu \mathrm{l})$ contained $5 \mu \mathrm{l}$ of heat-inactivated test serum and $5 \mathrm{ng}$ of heat-denatured ${ }^{125} \mathrm{I}$-ssDNA (calf thymus) in borate buffer. The mixture was incubated at $37^{\circ} \mathrm{C}$ for $1 \mathrm{~h}$ and then at $4^{\circ} \mathrm{C}$ for $16 \mathrm{~h}$. Precipitation was made by saturated ammonium sulfate. The amount of anti-ssDNA titers higher than 2 standard deviation values from the mean level of healthy subjects were regarded as positive $(>15 \%)$.

Statistically, student's $t$-test, Chi-square test and Spearman rank correlation analysis were used in this study. A $P$ value of more than 0.05 was considered not significant.

\section{Results}

Table 1 shows the incidence and mean level of CIC in patients with LL and SLE. CIC were demonstrated in 14 patients $(66.7 \%)$ with active LL, in 12 patients $(38.7 \%)$ with inactive LL, in 26 patients $(83.9 \%)$ with active SLE and in 10 patients $(33.3 \%)$ with inactive SLE. The mean level of CIC is $11.2 \mu \mathrm{g} / \mathrm{ml}, 6.4$ $\mu \mathrm{g} / \mathrm{ml}, 62 \cdot 1 \mu \mathrm{g} / \mathrm{ml}$ and $14.6 \mu \mathrm{g} / \mathrm{ml}$ respectively. Mean level of active SLE and LL is significantly high, compared with the control values described in Table 1 . There is a significant difference between active LL and inactive LL $(0.02<P<0.05)$. Active SLE has significantly high level of CIC, compared with the level in active LL $(P<0.001)$. However, statistical analysis shows no difference between inactive LL and inactive SLE.

Table 1. CIC in patients with LL and SLE

\begin{tabular}{llcccl}
\hline Patients & Stage & $\begin{array}{c}\text { No. } \\
\text { case }\end{array}$ & $\begin{array}{c}\text { No. positive } \\
(\%)\end{array}$ & $\begin{array}{c}\text { Mean level (SD)* } \\
\text { of CIC }(\mu \mathrm{g} / \mathrm{ml})\end{array}$ & $P$ value† \\
\hline LL & Active & 21 & $14(66 \cdot 7)$ & $11 \cdot 2(8 \cdot 3)$ & $P<0 \cdot 001$ \\
& Inactive & 31 & $12(38 \cdot 7)$ & $6 \cdot 4(6 \cdot 1)$ & not significant \\
SLE & Active & 31 & $26(83 \cdot 9)$ & $62 \cdot 1(60 \cdot 8)$ & $P<0 \cdot 001$ \\
& Inactive & 30 & $10(33 \cdot 3)$ & $14 \cdot 6(26 \cdot 9)$ & not significant \\
Control & & 25 & $1(4 \cdot 0)$ & $4 \cdot 6(2 \cdot 6)$ & \\
\hline
\end{tabular}

* SD means standard deviation.

$\dagger$ Results of student's $t$-test, compared with the CIC level of control. 
Table 2 shows the incidence and mean level of anti-ssDNA antibody in patients with LL and SLE. Anti-ssDNA antibody was demonstrated in 4 patients $(19.0 \%)$ with active LL, in 7 patients $(20.6 \%)$ with inactive LL, in 30 patients $(100 \%)$ with active SLE and in 22 patients $(73 \cdot 3 \%)$ with inactive SLE. The mean binding activity is $11 \cdot 8 \%, 12 \cdot 2 \%, 69 \cdot 2 \%$ and $29 \cdot 5 \%$ respectively. As shown in Table 2, there is no significant difference between active LL and control but significantly high activity of binding is demonstrated in inactive LL, active SLE and inactive SLE. In both active and inactive stage, SLE has significantly high activity of binding compared with LL $(P<0 \cdot 001)$.

We examined whether the amount of CIC was correlated with the levels of anti-ssDNA antibodies in sera with positive CIC. As shown in Figure 1, there is

Table 2. Anti-ssDNA antibody in LL and SLE

\begin{tabular}{|c|c|c|c|c|c|}
\hline Patients & Stage & $\begin{array}{l}\text { No. } \\
\text { case }\end{array}$ & $\begin{array}{c}\text { No. positive } \\
(\%)\end{array}$ & $\begin{array}{l}\text { Mean level (SD)* } \\
\text { of ssDNA Ab }(\%)\end{array}$ & $P$ value $\dagger$ \\
\hline \multirow[t]{2}{*}{ LL } & Active & 21 & $4(19 \cdot 0)$ & $11 \cdot 8(7 \cdot 6)$ & not significant \\
\hline & Inactive & 32 & $7(20 \cdot 6)$ & $12 \cdot 2(6 \cdot 4)$ & $0.02<P<0.05$ \\
\hline \multirow[t]{2}{*}{ SLE } & Active & 30 & $30(100 \cdot 0)$ & $69 \cdot 2(12 \cdot 6)$ & $P<0.001$ \\
\hline & Inactive & 30 & $22(73 \cdot 3)$ & $29.5(19.9)$ & $P<0.001$ \\
\hline Control & & 25 & $4(16 \cdot 0)$ & $9 \cdot 1(2 \cdot 9)$ & \\
\hline
\end{tabular}

* SD means standard deviation.

$\dagger$ Results of student's $t$-test, compared with the normal control.

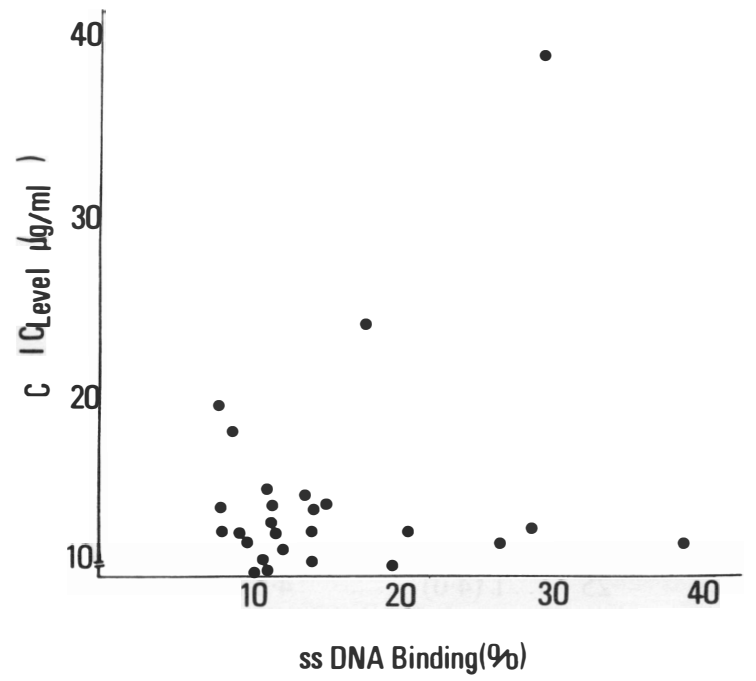

Figure 1. A lack of quantitative association between CIC and anti-ssDNA antibody in patients with LL $\left(r_{s}=-0 \cdot 023, P\right.$ not significant $)$. 
no significant association between these two serological abnormalities in LL by Spearman rank correlation analysis $\left(r_{s}=-0 \cdot 023, P\right.$ : not significant).

However, the significant association was found between them in SLE $\left(r_{s}=0 \cdot 56\right.$, $P<0.01$ ) (Fig. 2).

For the next step, we examined the effects of ssDNA on the levels of Clq binding activity. Preliminary, the pooled sera were obtained from LL, SLE and

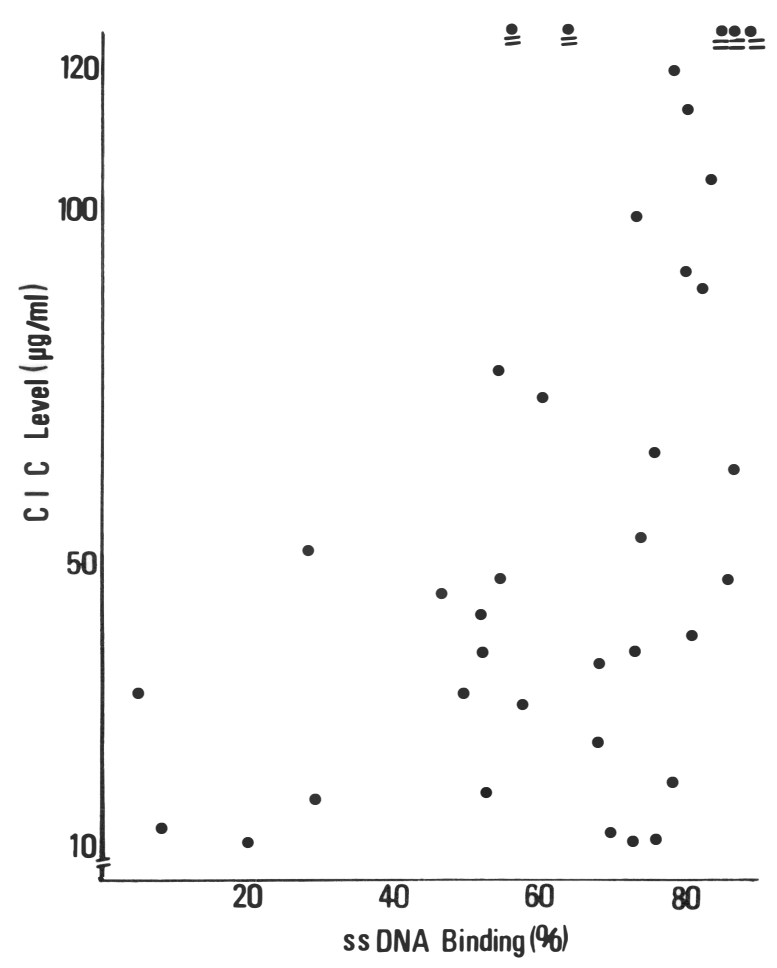

Figure 2. Significant association between CIC and anti-ssDNA antibody in patients with SLE $\left(r_{s}=0 \cdot 56, P<0 \cdot 01\right)$.

normal healthy (NHS) control and the inhibition tests were made. Fig. 3 showed that the reduction of $\mathrm{Clq}$ binding activity was demonstrated by addition of ssDNA solution. In healthy control, per cent inhibition at any concentration of ssDNA solution showed similar ratio but, in SLE and LL, it increased with the concentration and reached the maximum at the concentration of $100 \mu \mathrm{g} / \mathrm{ml}$. Therefore, $100 \mu \mathrm{g} / \mathrm{ml}$ was the optimal dose for this inhibition assay. We selected 8 serum samples from LL who showed positive level of CIC and also selected randomly 10 and 20 serum samples from SLE and healthy controls, respectively. The results of inhibition tests were shown in Fig. 4. Inhibition ratio was similarly low in LL and healthy controls $(0 \cdot 2<P<0 \cdot 3$; not significant $)$ but inhibition ratio of SLE was significantly high compared with the results of $\operatorname{LL}(P<0 \cdot 001)$. 


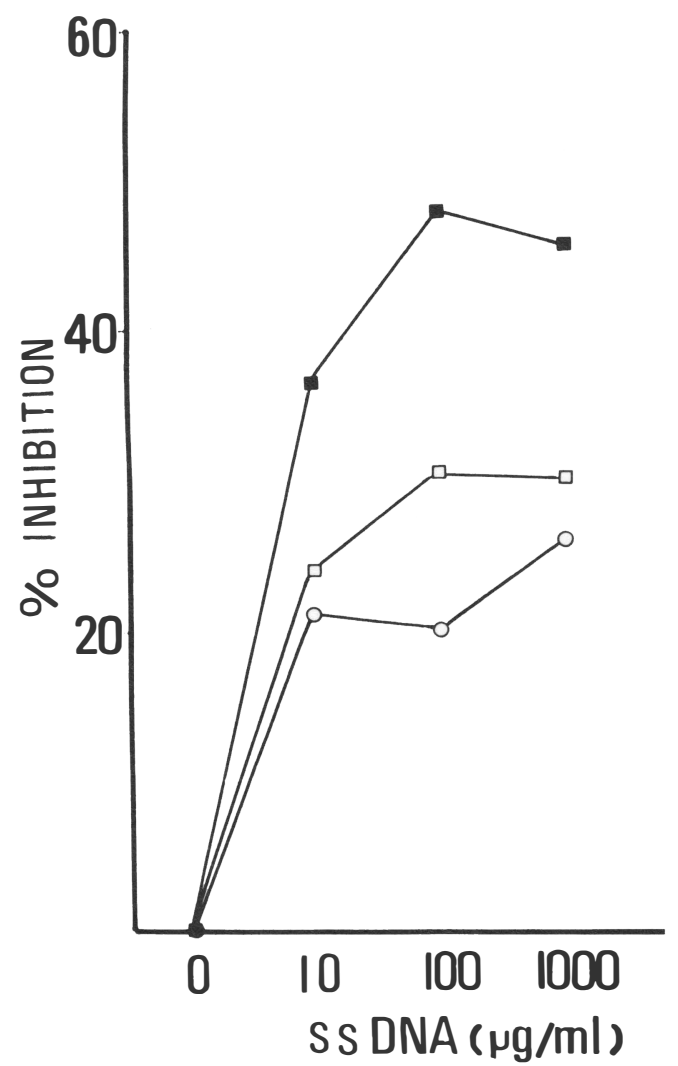

Figure 3. Dissociation of CIC in pooled sera by ssDNA solution. (ש) systemic lupus erythematosus, ( $\square$ ) lepromatous leprosy, (O) normal human serum (NHS).

\section{Discussion}

Patients with LL show abnormalities of humoral immunity and cellular immunity. ${ }^{10}$ The disturbance of humoral immunity in LL is characterized by the appearance of $\mathrm{CIC},{ }^{11}$ autoantibodies ${ }^{12}$ and variations in the levels of serum immunoglobulins. ${ }^{13}$ Recently we investigated the incidence of CIC and anti-DNA antibodies in sera of patients with LL and demonstrated the presence of CIC and anti-ssDNA antibody and relative absence of anti double-stranded DNA antibody. ${ }^{4}$ Similar immunological disorders are also found in sera of patients with SLE.

Of special interest is whether or not the serological mode of the appearance of CIC and autoantibodies in LL has the similarity to those found in SLE. In 1981 Nuti et al. ${ }^{1}$ examined CIC and autoantibodies in sera of patients with LL and found the significant correlations between CIC level and the appearance of autoantibodies. However, Malaviya et al. ${ }^{14}$ studied the immunoglobulin levels, 


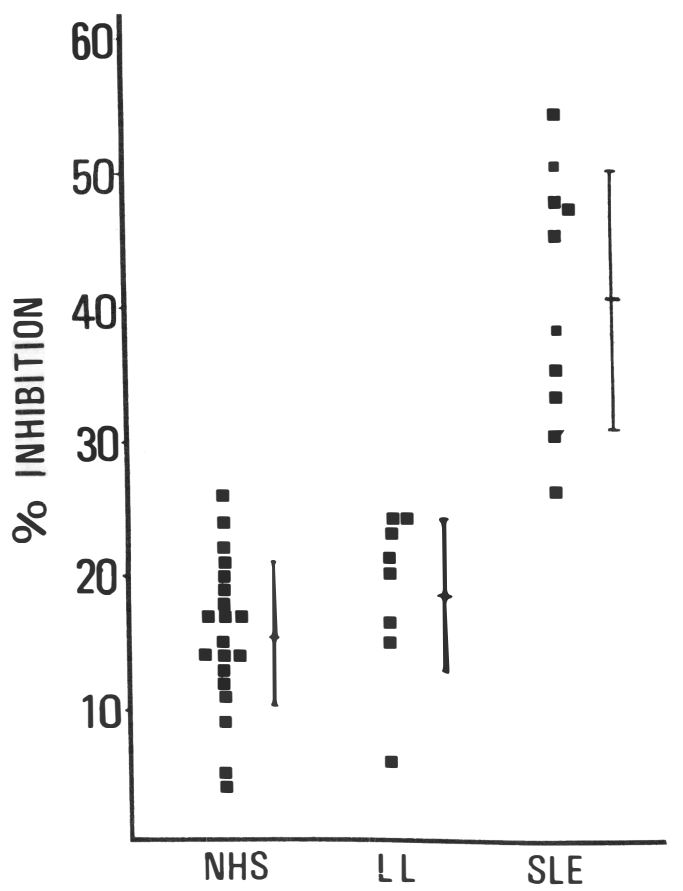

Figure 4. Reduction of $\mathrm{Clq}$ binding activity by ssDNA solution. NHS; normal human serum (control), LL; lepromatous leprosy, SLE; systemic lupus erythematosus. Bar represents the mean level \pm one standard deviation.

autoantibodies, hepatitis-associated antigens and C-reactive protein in sera of patients with LL and concluded that the presence of autoantibodies in leprosy was only a paraphenomenon, suggesting that leprosy is not an autoimmune disease.

CIC in LL and SLE are well known to correlate significantly with clinical features. ${ }^{15,16}$ Although anti-ssDNA antibody in SLE is one of clinical indicators, this antibody in LL does not reflect the clinical features because the incidence and the mean level of anti-ssDNA antibody were higher in inactive stage than active stage. However, the statistical analysis revealed that the appearance of antissDNA antibody in LL had the significance and, therefore, we evaluated the anti-ssDNA antibody as a parameter of polyclonal B cell activation. Taking account of these findings, we selected 2 serological tests, CIC and anti-ssDNA antibody, in order to verify the values and the mode of serological abnormalities in LL.

The incidence of CIC in each stage of LL was almost similar to that of SLE but CIC level in active SLE was significantly high compared with active LL. The incidence of anti-ssDNA antibody in LL was lower than in SLE and there was a significant difference in the amount of this antibody between LL and SLE in each 
stage. A markedly quantitative difference was present in the appearance of CIC and anti-ssDNA antibody between LL and SILE. Quantitative correlation studies revealed that there was a significant association between CIC and anti-ssDNA antibodies in SLE but not in LL. This result in SLE was compatible with other reports. ${ }^{15,16}$ Based on these results, we could clearly discriminate the mode of CIC and anti-ssDNA antibody in LL from that in SLE.

A few important questions raised by these data are as follows: (1) the identification of antigen involved in CIC of LL and SLE; and (2) the mechanisms of abnormal production of CIC and anti-ss DNA antibody.

Firstly, inhibition study suggested that CIC in LL did not contain the ssDNA as antigen but CIC in SLE had in part ssDNA or related substances. Similar inhibition studies were tried using phenolic glycolipid-I but in vain because this was not soluble in the medium or buffer solution used in this study. However, we have already showed the significant association between CIC and bacteriological index, which suggested the possibility that $\mathrm{CIC}$ contained $M$. leprae related substances as antigen. ${ }^{3}$

Secondly, the mechanism of abnormal production of CIC and anti-ssDNA antibody could result from polyclonal $\mathrm{B}$ cell activation. The causative factors responsible for polyclonal $\mathrm{B}$ cell activation are still unknown.

Regardless of the cause of polyclonal B cell activation, special attention should be given to the fact that the mode of serological abnormalities or polyclonal B cell activation in LL was different from that in SLE. In a few recent publications from our laboratory, it was reported that natural thymocytotoxic autoantibodies (NTA) and anti-DNA antibodies in New Zealand mice did not correlate with anti-dinitrophenyl (DNP) IgM antibodies, which was one of the parameters of polyclonal B cell activation. ${ }^{17,18}$ The same results were demonstrated in sera of SLE. ${ }^{19}$ However, there were significant associations among NTA, anti-DNA antibodies and CIC in SLE. In contrast, such significant relationships were not found in LL. Polyclonal B cell activation is not considered to appear in the same pattern. It is important to clarify the polyclonal B cell activator, disease by disease. The animal studies using the administration of phenolic glycolipid-I are now under investigation.

\section{Acknowledgment}

This work was supported by a grant from the Ministry of Health and Welfare, Japan. We thank Mr Kanji Tsuchida and Ms Keiko Shimizu for preparation of the manuscript.

\section{References}

1 Nuti M, D’Amelio R, Seminara R, Milano CF, Palmisano L, Aiuti F. Circulating immune complexes detected by Clq solid phase assay in leprosy. Int J Lepr, 1981; 49: 27. 
2 Masala C, Amendolea MA, Nuti M, Riccarducci R, Tarabini CGL, Tarabini CG. Autoantibodies in leprosy. Int J Lepr, 1979; 47: 171.

${ }^{3}$ Furukawa F, Ozaki M, Imamura S, Yoshida H, Pinrat A, Hamashima Y. Associations of circulating immune complexes, clinical activity and bacterial indexes in Japanese patients with leprosy. Arch Dermatol Res, 1982; 274: 185.

${ }^{4}$ Furukawa F, Sekita K, Hamashima Y, Ozaki M, Imamura S. Evaluation of circulating immune complexes and antinuclear antibodies in Japanese patients with leprosy. Arch Dermatol Res, 1983; 275: 144.

5 Ridley DS, Jopling WH. Classification of leprosy according to immunity. A five-group system. Int J Lepr, 1966; 34: 255.

6 Japanese leprosy committee. Clinical classification of leprosy. Lepra, 1959; 28: 391.

7 Cohen AS, Reynold WE, Franklin EC, Kulka JP, Ropes MW, Shulman LE, Wallance S. Preliminary criteria for the classification of systemic lupus erythematosus. Bull Rheum Dis, 1971; 21: 643 .

${ }^{8}$ Hay FC, Nineham LJ, Roitt IM. Routine assay for the detection of immune complexes of known immunoglobulin in class using solid phase C1q. Clin Exp Imm, 1976; 24: 396.

9 Yoshida H, Kohno A, Ohta K, Hirose S, Maruyama N, Shirai T. Genetic studies of autoimmunity in New Zealand mice. III. Associations among anti DNA antibodies, NTA, and renal disease in $(\mathrm{NZB} \times \mathrm{NZW}) \mathrm{F}_{1} \times \mathrm{NZW}$ backcross mice. $J \mathrm{Imm}, 1981 ; 127: 433$.

10 Bullock WE. Studies of immune mechanisms in leprosy. 1. Depression of delayed allergic response to skin test antigen. New Eng J Med, 1968; 278: 298.

${ }^{11}$ Moran C, Rydr G, Turk JL, Water MFR. Evidence for circulating immune complexes in lepromatous leprosy. Lancet, 1972; ii: 572.

12 Nattews LJ, Trautman JR. Clinical and serological profiles in leprosy. Lancet, 1965; ii: 915.

13 Bullock WE, Ho MF, Chen MJ. Studies of immune mechanisms in leprosy 11. Quantitative relationship of IgG, IgA and IgM immunoglobulin. J Lab Clin Med, 1970; 75: 863.

${ }^{14}$ Malaviya AN, Pasricha A, Pasricha JS, Mehta JS. Significance of serologic abnormalities in lepromatous leprosy. Int J Lepr, 1972; 40: 361.

${ }^{15}$ Cano PO, Jerry LM, Sladowski JP, Osterland CK. Circulating immune complexes in systemic lupus erythematosus. Clin exp Imm, 1977; 29: 197.

${ }^{16}$ Devis P, Cumming RH, Varrier-Jones J. Relationship between anti DNA antibodies, complement consumption and circulating immune complexes in systemic lupus erythematosus. Clin exp Imm, 1977; 28: 226.

${ }^{17}$ Hirose S, Maruyama N, Ohta K, Shirai T. Polyclonal B cell activation and autoimmunity in New Zealand mice 1. Natural thymocytotoxic autoantibody (NTA). J Imm, 1980; 125: 610.

${ }^{18}$ Hirose S, Yoshida H, Ohta K, Nakai Y, Maruyama N, Shirai T. Polyclonal B cell activation and autoimmunity in New Zealand mice: Anti DNA antibodies and proteinuria. In New Horizons in Rheumatoid Arthritis, Shiokawa Y, Abe T, Yamauchi Y (eds), Excerpta Medica, Elsevier North-Holland, 1981, 102.

19 Shirai T, Hirose S, Furukawa F, Yoshida H, Sano H, Hamashima Y, Yumura K. Polyclonal B cell activation and anti DNA antibodies in systemic lupus erythematosus. Annual reports of the Ministry of Health and Welfare Research Committee of Japan. 1982, 130. 